\title{
Measuring Women's Influence on Roman Military Life: using GIS on published excavation reports from the German frontier
}

\author{
Author's details \\ Penelope Allison \\ School of Archaeology and Ancient History, University of Leicester, University Road, \\ Leicester LE1 7RH, United Kingdom \\ pma9@le.ac.uk
}

Keywords: intra-site analyses, Roman forts, Germany, artefact distribution, women and children

This article will appeal to archaeologists, and especially Roman archaeologists, interested in using artefact distribution to investigate social behaviour.

\section{Table of Contents}

Summary

List of Figures

1 Introduction

2 The Background

2.1 Roman authors

2.2 Roman officers' families

2.3 Ordinary Roman soldiers families

2.4 Other women inside the fort

2.5 Summary

3 The Data

4 The Procedures

4.1 Digitising the data

4.2 Categorising the data

4.3 Assessing robustness of artefact distribution patterns

5 Some Results

5.1 Vetera I

5.2 Rottweil

5.3 Oberstimm

5.4 Ellingen

6 Discussion

6.1 Presence, habitation and roles of women in these forts

6.2 Implications of the presence of women within these forts

7 Concluding Remarks

Acknowledgements

Bibliography

\section{Abstract}


This article outlines the approaches used in the Australian Research Council funded project, 'Engendering Roman Spaces', and summarises some of the results. The project investigates the distribution of artefacts and artefact assemblages and the presence, activities and status of women and children within Roman military forts. It uses data from published excavation reports of 1st- and 2nd-century AD Roman military sites on the German frontier. It includes excavation reports from throughout the 20th century, which have varying levels of comprehensiveness.

The relevant data from these excavation reports are digitised and manipulated, through a series of software packages, and then classified according to gender and function, so that spatial distribution patterns of people's activities can be visualised and analysed using GIS. Interpretations of these data are indicating that women played a greater role in military life in the early Roman Empire than has previously been acknowledged.

\section{Introduction}

This section article outlines the approaches of the research project, 'Engendering Roman Spaces', which commenced in 2001. In this project GIS visualisation assists the detailed, small-scale analyses of inter- and intra-site distribution patterns of artefacts that have been assigned social significance, or more specifically task and gender values. This particular project investigates small-scale, intra-site patterning within structurally defined areas using 'legacy data' and pseudo-GIS environments [LINK to glossary]. In addition, it uses the spatial analyses of socially classified data to investigate social, and particularly gendered, behaviour (for full publication: Allison forthcoming).

In discussing the mapping of gendered behaviour, Silvia Tomášková recently questioned (2006, 25) 'whether [GIS] is the best tool for all the questions we may wish to ask'. She cited feminist geographers (e.g. Kwan 2002a, 2002b) as questioning the usefulness of GIS techniques for such interpretative and qualitative investigations. However, contra Tomášková, Kwan (2002a, esp. 272-4) advocated that GIS techniques are indeed useful for both 'quantitative/empiricist' and critical/qualitative analyses. She called for 'more diverse and nuanced reading of complex relationships among GIS technology, data, social and political institutions, application contexts, and the agency of the actors involved'.

As mentioned in the introduction to this volume [?LINK], I am concerned with processes for dealing with data of uncertain meaning or significance and this is particularly pertinent to processes for the social and gender classification of archaeological data and to Tomášková's 'multiple plausible scenarios' in investigations of the data (Tomášková 2006, 25). Using Hans-Jürgen Zimmermann's language concerning Fuzzy Set Theory [LINK to glossary] and its application to Fuzzy Logic and Fuzzy Data analysis, I am interested in uncertainty and imprecision resulting from an 'absence of sharply defined criteria of class-membership rather than the presence of random variables' (Zimmermann 2001, 6). The imprecision in the 'Engendering Roman Spaces' project involves a 'vagueness' in the meaning of the data and not simply 'a lack of knowledge' about it. 
Two of our main problems in archaeology are, firstly, the randomness of our sample and, secondly, our lack of precise knowledge about past human social behaviour. We tend to believe that we can compensate for the former by choosing a large sample. I believe that the imposition of a condition of 'vagueness ... about the value of a parameter' (Zimmermann 2001, 6) can serve to compensate for our lack of knowledge about meaning and significance in the past, knowledge that may only ever be partially achievable (see also Hermon <em>et al</em>. 2004).

In this project I am concerned with imprecision and uncertainty on two levels: uncertainty about the identification of the activities with which particular artefacts would have been associated; and uncertainty about the social and gender identities of the people associated with such activities. For example, particular types of bone, ceramic and stone discs may have been used as spindle whorls and spinning seems to have been a female activity in the Roman world. The concepts of uncertainty in Fuzzy Set Theory as deriving from a continuum of related values; as involving the intersections and unions of a number of sets; and as being related to degrees of membership of a set or a union of sets, seem to fit well with my own data and objectives, and to validate the use of GIS techniques to present and analyse socially classified data.

In his definition of fuzzy data analysis, Zimmermann $(2001,279)$ presents four possibilities for data classification: crisp objects and crisp classes; crisp objects and fuzzy classes; fuzzy objects and crisp classes; and fuzzy objects and fuzzy classes. My data, and indeed most archaeological data, fall into Zimmermann's first, second and fourth possibilities. Without a precise identification of the actual artefacts it is difficult, if not impossible, to assign them to a specific type or class. But my two levels of uncertainty also constitute two levels of more or less 'fuzzy' classes. Given both the quantity and quality of these data and their respective classes, any attempts to model them mathematically, and then relate that modelling to their GIS presentation, is likely to ascribe an unjustifiable level of precision. However, Zimmermann's distinction between 'mathematical pattern recognition' and more context-dependent 'non-mathematical pattern recognition', and his comment that the most effective search procedure is the 'eyeball' technique (Zimmermann 2001, 277-8), suggests that a more straightforward GIS environment is probably an ideal environment in which to analyse such data.

In the 'Engendering Roman Spaces' project, a GIS-type environment is used to visualise and analyse artefact distribution patterns in 1st- and 2nd-century Roman military bases to investigate for the presence and roles of women and children within these, traditionally viewed, male-dominated domains.

\section{The Background}

\subsection{Roman authors}

Some Roman authors wrote about the inappropriateness of women and families in combat zones. Herodian ( $<\mathrm{em}>$ Histories $</ \mathrm{em}>$, 3.8.4) considered wives a hindrance to military discipline, and Juvenal (<em>Satires $</$ em $>$, VI.398-405) was sharply critical of those women who, 'with unflinching face and hard breasts' participated in male 
discussions of politics and military matters. The views of such authors have supported a widely held perception among modern scholars that the Roman frontier, like the military zones of the 17th-early 20th centuries, was no place for women and families (Phang 2001, 1-2).

But other ancient authors indicate that wives, families, tradespersons, artisans and slaves, did indeed accompany the Roman army on campaign. Caesar mentioned baggage trains of the carts of camp followers and merchants carrying their wares, during his African campaigns (<em>de Bello Africano</em>, 75) and Cassius Dio (LVI.20.2-5) noted that 'not a few women and children and a large retinue of servants' followed the marching column of Varus [LINK to glossary] when he led the Roman legions to a disastrous defeat by the Germans in AD 9. Such 'camp-followers' and their impact on this frontier community have taken a more prominent place in recent investigations of the Roman military (e.g. Goldsworthy and Haynes 1999). However, the general understanding is still that, for the early empire, the only families accommodated inside military forts were those of the camp commander and of senior officers.

\subsection{Roman officers' families}

Wooden writing tablets found at the fortress of Vindolanda, near Hadrian's Wall in northern England (Birley 1977, 125; Bowman and Thomas 1994, no. 291), give evidence for the residency of wives of at least two commanding officers in this frontier region prior to AD 103. And the residences of commanding and senior officers were often laid out and furbished in a seemingly appropriate manner for a household comprising a family and servants - spacious courtyard houses with hypocaust heating [LINK to glossary], wall-painting, sculpture, and private bath-suites, similar to well appointed urban and rural houses (Hoffmann 1995, 140). There is also evidence to suggest that centurions' families may have accompanied them in their quarters (see Hoffmann 1995; Hassall 1999, 35-36; Phang 2001, 130-2).

\subsection{Ordinary Roman soldiers' families}

It has been widely believed that other non-military personnel, such as tradespersons, were housed in settlements outside the fort, the $\langle\mathrm{em}>$ vici</em> and the <em>canabae $</ \mathrm{em}\rangle$ [LINK to glossary] and that there were no families of other serving men in this community because ordinary soldiers were not permitted to marry during the early empire (e.g. Garnsey 1970, esp. 48; Smith 1972, esp. 497; Southern and Dixon 1996, 85). The Emperor Augustus is thought to have banned the marriage of soldiers during active service (Phang 2001, 16-17), a ban that was lifted two centuries later, in AD 197, by the Emperor Septimius Severus [LINK to glossary] who allowed these soldiers to 'wear the gold ring and live [in marriage?] with their wives' (Herodian, <em $>$ Histories $</ \mathrm{em}\rangle$, 3.8.4-5). Most scholars have assumed, therefore, that this legal ban resulted in an absence of ordinary soldiers' families, certainly from inside forts, prior to the end of the 2nd century.

Sara Phang (2001) has analysed textual evidence, such as tomb inscriptions, papyrus letters, and bronze military diplomas and concluded that, during the early empire, ordinary soldiers indeed had 'wives', if in a $<\mathrm{em}>$ de facto $</ \mathrm{em}>$ sense, who accompanied 
them and produced children while on active service. But these documentary sources give little indication as to where these '<em>de facto</em>' families would have lived.

At Vindolanda remains of small-sized shoes have been found within the barracks of ordinary soldiers, dating to the beginning of the 2 nd century $\mathrm{AD}$, and have been identified by Carol van Driel Murray as those of women and children $(1994 ; 1995 ; 1997)$. These barracks do not have the elaborate layout and furnishing of officers' quarters, which have been widely assumed to be necessities for female accommodation (see Petrikovits 1975, 134-5).

\subsection{Other women inside the fort}

Evidence for women inside military bases has also been found associated with the 1stcentury legionary fortress at Vindonissa, in Switzerland. Some of the wooden writing tablets found on the rubbish heap of this fortress recorded house numbers and individual's names, demonstrating that there had been inns and taverns, or perhaps brothels, inside the fortress, where female barmaids and innkeepers worked (Speidel 1996, 55, 80). This evidence from Vindonissa does not actually verify the residency of these women within this legionary fortress, but it suggests that they were employed inside the fort proper in establishments that were highly likely to have provided accommodation for their staff.

\subsection{Summary}

Scholars have used textual evidence and the structural remains of officers houses' to argue that their families accompanied them on campaign. More recent analyses of the written evidence indicate that ordinary soldiers also had wives and families while on active service. But, because there appears to have been no allowance for the accommodation of such families in the structural layout of barrack buildings, most military scholars, including Phang (2001, 127-9), argue that these families must have lived in the settlements outside the fort. But the findings of women's and children's shoes at Vindolanda, and the evidence from the wooden tablets at Vindonissa suggest that at least some such people were likely to have been accommodated within the fort proper. Van Driel Murray stressed that, 'It is to whole packages of attributes that we must look' to understand the statuses and roles of the women and children in these, long-considered, male domains. She also wrote $(1997,60)$ that, '[o]nce it is accepted that women did form a significant section of the camp population, we can begin to develop material correlates by means of which their social and economic roles can be investigated'.

\section{The Data}

I have undertaken the task of analysing artefact distribution patterns within 1st- and 2ndcentury Roman military bases to investigate what information they might provide about the communities that lived inside these military bases and whether these communities might include women and families who seem not to have been part of officers' households. One of my main problems has been obtaining suitable data to analyse. Most Roman archaeologists with digitised data are still collecting or using these data, and so they are not in a form that is readily usable for the type of analyses I would like to carry 
out. However, there is a strong tradition in Germany of detailed and comprehensive publication of the data from the excavations of Roman period sites. So I have analysed a number of published excavation reports for sites from the Roman provinces in Germany that seem best suited to my purposes. My criteria are essentially: that the military bases had a short occupancy and rapid, or relatively rapid, abandonment, such that there is a certain amount of integrity in their artefact assemblages; that the excavation reports have good site maps and plans, showing excavated areas clearly; and that these reports have relatively comprehensive artefact catalogues with provenance information.

The four main sites that I have analysed are, in chronological order: the double legionary fortress of Vetera I, near the town of Xanten in the Lower Rhine region; the legionary fortress and cohort fort at Rottweil on the Neckar River (a major right tributary of the Upper Rhine); the auxiliary fort [LINK to glossary] at Oberstimm in the Upper Danube Region; and the auxiliary fort at Ellingen, also in the Upper Danube Region (Fig. 1[LINK to PAFigure1.jpg]). As a comparison for the quality of the data from these sites I have also analysed the artefact distribution patterns of the early 2nd-century auxiliary fort at Hesselbach (see Baatz 1973) which was not rapidly abandoned and suffered from erosion. It therefore serves as a control for the nature and quality of the data at the other four sites.

\section{The Procedures}

4.1 Digitising the data

Having selected these forts, their published catalogues and the plans were digitised, imported into graphics and spreadsheet programmes, and then exported into a GIS programme. These procedures are discussed by Allison $\langle$ em $>$ et al $</ \mathrm{em}\rangle$. in this volume [LINK to AllisonetalProblems.doc] (see also Allison <em>et al</em>. 2004 Section 6 [LINK TO ALLISON IN INTERNET ARCHAEOLOGY 17]).

\subsection{Categorising the data}

Creating the spreadsheets that were composed from the artefact catalogues required a considerable amount of work, not least in translating the German, but also in standardising the fields for the resulting databases, with and between the sites, and, most importantly, in adding fields with task- and gender-related values. This social categorisation is undoubtedly subjective but most of the categories are suggested, rather than defined. They were intended for pattern exploration and are 'vague' and 'fuzzy', rather than defined categories. Ascribing task and gender-related values to Roman artefacts requires critical approaches to artefact function and to our understanding of the activities and dress of men, women and children in the early Roman Empire.

Additionally, this had to be done without too much analogical inference and with an awareness that, in our society of mass-production, we are often too inflexible about the potential multiplicity of functions, and meanings, of many excavated Roman artefacts. There is not space here to discuss all the reasons for all the ascriptions that underpin this project (see Allison <em>et al</em>. 2004, esp. sections 3.2 and 8 [LINK TO ALLISON IN INTERNET ARCHAEOLOGY 17]; Allison forthcoming), so I will just give a couple 
of brief examples which stem from my consumption approach to artefact assemblages found in Pompeian houses (Allison 1993; 1999; 2004; 2006a).

Two pendants were found together with other precious items, in a casket in room 35 in the House of the Menander (Allison <em>et al</em>. 2004, fig. 6 [LINK TO ALLISON IN INTERNET ARCHAEOLOGY 17]; Allison 2006a, pl. 47.11). These types of pendants are widely assumed to be associated with military dress, worn either by men to decorate their armour (Robinson 1975, pls 245 and 423) or by horses to decorate their harness (Bishop 1987; 1988). Therefore, these pendants could be categorised as 'combat equipment' or 'horse equipment'. But this classification would not suit the pendants in this Pompeian context. At least three such pendants were found in domestic contexts in the Insula [LINK to glossary] of the Menander (Allison 2006a, cat. nos 671 and 1724) and about ten in a study of thirty Pompeian households (see Allison 2004, on-line companion). While not numerous, these pendants are indeed present in domestic contexts and therefore form part of domestic assemblages. Such pendants are also found in nonmilitary contexts, elsewhere in Italy (see e.g. Quilici 1974, 73, 75 fig. 26).

The collection in room 35 in the House of the Menander might be considered as a $<$ em>mundus muliebris</em>, reportedly a women's toilet box that contained gold, silver, toilet equipment, jewellery, perfumes, clothing, and statues (see $<\mathrm{em}>$ Digesta $</ \mathrm{em}>34.2$ ). This suggests that the pendants may have been worn by a woman, even if they were keepsakes from her military husband, and that this context documents their association with female activity. I would therefore classify these types of pendants in Pompeii, with more uncertainty, as either 'dress', 'combat equipment' or 'horse equipment' and as 'possibly male or female' items. If this 'vague' classification applies to Pompeian houses, then it may also apply to military sites.

Among other artefacts that have a possible gender association are those associated with cloth production. Cloth production is 'symbolically associated with women' in the classical world (Kampen 1996, 22), but both men and women were involved in weaving in the Roman world (Treggiari 1976, 81-5; Dixon 2001, 117-29) and Allason-Jones has argued $(1995,28)$ that needlework, possibly in the form of mending, could be carried out by the soldiers themselves. I have, therefore, classified weaving and needlework as 'possibly a male or female' activity. On the other hand, although there is evidence for men spinning in other cultures (Nandris 1981, 251), there is no evidence to substantiate that this was the case in the Roman world, but much to the contrary (see Deschler-Erb 1998, 136-7; Treggiari 1976, 82). So I have classified spinning as a 'definitely female' activity.

While spindle whorls were pierced discs of either stone, bone, ceramic or glass, and are frequently found on excavation sites, it is not always possible to establish if a pierced disc was used as a spindle whorl. Pierced glass and bone discs, of various types, were found in the Insula of the Menander in Pompeii (e.g. Allison 2006a, cat. nos 44, 113-16, 557, 679, 1048-49, 1449-57, 1904; see also Allison 2006b, fig. 1). Thanks to the associations of many of these it was possible to construct a simple typology of the types that were most likely to have been used, respectively, as jewellery, spindle whorls, or furniture 
decoration, not forgetting that some, particularly beads, might have been reused as gaming counters (Allison 2006a, 380-1; also Allison 2006b, table 1).

Using such an approach to artefact categories, I have ascribed activities and gender associations, or more precisely a range of activities and possible gender associations, to the recorded artefacts from the forts and fortresses in my study. There is obviously a certain amount of subjectivity in these ascriptions. Also some of these categories, particular gender categories, have changed over the life of the project as further research has been carried out on specific types of artefacts For example, Böhme-Schönberger's more recent studies of brooches (e.g. Böhme-Schönberger 2002) has required changes to the gender categorisation of some of these. The aim of this project is not to substantiate these categorisations, but rather to explore the distribution patterns of these rather vague and fuzzy categories. For the purposes of this study, artefacts that are potentially associated with children, including infant skeletons, are discussed under gender, although this is not a strictly accurate categorisation (see Casella 2006, 27). This is because some items have been identified as belonging to either women or children (e.g. certain beads: see Allason-Jones 1995, 27). In addition, in this particular context, remains of children and their activities suggest the presence of women.

\subsection{Assessing robustness of artefact distribution patterns}

Of concern to this and similar studies is whether the observed distribution patterns of specific artefact categories documented activities and behaviours during the fort's occupancy, or whether they resulted from post-depositional activity. Because ceramics are the most prolific class of material, distribution plots and density graphs for the ceramics from each site were compiled and used to assess whether any differences would actually reflect variations in spatial behaviour or could have resulted from site formation processes or selective excavation procedures (for Ellingen see Allison 2007, 397-403; for all sites see Allison forthcoming). Although certain anomalies were observed and had to be accounted for in the study, such as the density of artefacts in Building $\mathrm{C}$ at the fort at Ellingen, these ceramic tests generally showed that the observed patterns were fairly robust and could be interpreted as relating to activities during occupation of these forts.

\section{Some Results}

The following discussion is a brief summary of some of the results from the project, concerning evidence for women and children in these particular sites. These results demonstrate how the complex information in the original excavation reports has been reduced to activity and gender categories whose spatial distribution within these military bases can be plotting using a GIS-type environment.

\subsection{Vetera I}

The stone-built double legionary fortress of Vetera I was constructed $\langle\mathrm{em}>\mathrm{c}</ \mathrm{em}\rangle$. AD 40 and covered an area of about 15 hectares. It replaced earlier wooden fortresses, dating from the early Augustan period ( $\langle\mathrm{em}>\mathrm{c}</ \mathrm{em}\rangle .12 \mathrm{BC})$. The final fortress was abandoned $<\mathrm{em}>\mathrm{c}</ \mathrm{em}>$. AD 70, reportedly after an uprising among the locally recruited troops, the Batavians. Excavations were carried out here at the beginning of the 20th century (Lehner 
$1907 ; 1912 ; 1930)$ and the site and excavation trench plans and artefact catalogues were comprehensively published by Norbert Hanel in 1995.

The distribution patterns of artefacts from within the fortress that can be ascribed a gendered task or activity (e.g. combat, metal-working, cloth production, toilet, dress, etc.), can be plotted according to gender (Fig. 2[LINK to PAFigure2.jpg]; see Allison <em>et al</em>. 2004 for ArcIMS plots of the Vetera material [LINK TO ALLISON IN INTERNET ARCHAEOLOGY 17]). As one might expect, the majority of artefacts at this site are male-related, or probably male-related. But there is also a scattering of items that are female-related, probably female-related, or probably female- or child-related.

By removing all the male-related artefacts, it is possible to show only activity and dress items that are potentially female- or child related (Figure 3 [LINK to PAFigure3.jpg] this plot has been updated since Allison <em>et al</em>. 2004, section 8.6.2c, and Allison 2006b, fig. 4). These artefacts cluster in the gateways and the main cross street, and in the commanding officer's palace and in the senior officers' houses. The artefacts categorised as potentially female- or child-related tend to be associated with definitely female-related items and they cluster together, irrespective of type. This implies that there is some validity in my gender ascriptions. This distribution pattern would also conform to the accepted view that women and children within this 1st-century legionary fortress were either members of officers' households or traders from outside the camp frequenting the main street and market areas. The only apparent anomalies are a handful of possibly female- and child- related items, scattered across the central administrative buildings, but no definite female ones were found associated with these particular buildings.

Irrespective of this anomaly in the spatial plots, correspondence analysis indicates that the main pattern is fairly robust, with women's and children's items clustering with officer's quarters and street areas, and male items with administrative buildings and barracks (Graph 1 [[LINK to PAGraph1.jpg]; see also Allison et al. 2004, fig. 29 [LINK TO ALLISON IN INTERNET ARCHAEOLOGY 17]). Unfortunately, though, at Vetera I, only the central area was excavated, so little is actually known of the soldiers' barracks, a questionable realm for the presence of women and children.

\subsection{Rottweil}

The two forts on the left bank of the Neckar River at Rottweil, Forts I and II, were the fourth and fifth of five Roman forts constructed in this area, the others being built on the right bank of the river. The legionary fortress, Fort I, was constructed of wood and earth and covered some 16.6 hectares. The 11th legion, or part of it $(<\mathrm{em}>\mathrm{c}</ \mathrm{em}>.6000$ troops), moved here from Vindonissa $\langle\mathrm{em}>\mathrm{c}</ \mathrm{em}\rangle$. AD 75 and no doubt occupied this fortress. However, Fort I lasted only about ten years. It was replaced in $\langle e m\rangle c</ e m\rangle$. AD 85 with a smaller stone fort, Fort II, which was built inside the former fortress, along the same axis and sharing the same buildings and street arrangement. This smaller fort was probably occupied by a double cohort (<em $>c</ e m>.1200$ troops) and a $<\mathrm{em}>$ vexillation $</ \mathrm{em}>$ [LINK to glossary] or detached unit, and abandoned $<\mathrm{em}>\mathrm{c}</ \mathrm{em}>$. AD 110-120. The majority of the excavations of Forts I and II comprised piecemeal urban rescue excavations, carried out from the early 1980s until the mid- 
1990s, so only a small proportion of these two forts has been excavated. These excavations were compiled and published by Regina Franke (2003).

Figure 4 [LINK to PAFigure4.jpg] shows the distribution of artefacts associated with gendered activities within the excavated areas of Forts I and II at Rottweil, here plotted according to activity rather than gender as in the Vetera plot (Fig. 2[LINK to PAFigure2.jpg]). Compared with the other three sites analysed, there is a general lack of material and particularly metal artefacts at this site. This is no doubt due to the seemingly less dramatic abandonment of Fort II. Nevertheless, a relative concentration of material is observable in the central area of the fortress, identified by Franke (2003, 52-6) as an administrative building and workshop. These artefacts were found in canals and ditches and are among the wealth of material from destruction levels of the second phase of Fort I, when this fortress burnt down (Franke 2003, 93).

Figure 5 [LINK to PAFigure5.jpg] shows the distribution of female- and child-related artefacts. They are not very prolific, in common with all gendered artefacts in this fort (Fig. 4[LINK to PAFigure4.jpg]).Their presence alone in these parts of the fort is significant. They are also relatively prolific in the central area, and might be used to support an argument for a commanding officers' residence here. As at Vetera, they are also found in the main street and in what has been identified as an officer's residence in the south-east corner. Further examples are found in a latrine belonging to Fort II. Whatever women were doing in these two early forts at Rottweil, they were there.

These two legionary fortresses at Vetera and Rottweil conceivably conform to the traditional view that women were either members of officers' households or traders coming in along the main street. However, there is insufficient evidence of the ordinary soldiers' barracks in either of these sites to reach any conclusions about the presence or otherwise of women and children in such areas.

\subsection{Oberstimm}

The auxiliary fort at Oberstimm covered an area of $\langle\mathrm{em}\rangle \mathrm{c}</ \mathrm{em}\rangle .1 .75$ hectares. It was occupied in two different phases between $\langle$ em $>$ c $</$ em $>$. AD 40- AD 120. It was excavated by Hans Schönberger between 1968 and 1971, who suggested $(1978,148)$ that it was a supply station, near the border, for troops further to the east.

Artefacts from Oberstimm are plotted according to associated gendered activities, as at Rottweil (Fig. 6 [LINK to PAFigure6.jpg] - this plot has been updated since Allison 2006b, fig. 8). The most prolific material is combat equipment, and also stone- and metalworking equipment. The combat equipment was found mainly in Building 7 , the commanding officer's residence, and in Building 6, the soldiers' barracks. The stone- and metal-working equipment, was found mainly in Building 1 and in the area of Building 3. Schönberger identified Building 1 as an industrial area, and Building 3 as accommodation for craftsmen soldiers, the <em>immunes </em> [LINK to glossary] (Schönberger 1978, 45-6, 70-3). 
Artefacts potentially associated with the women and children were scattered across the excavated areas of the fort (Figure 7 [LINK to PAFigure7.jpg] - this plot has been updated since Allison 2006b, fig. 5). Definite female- and child-related artefacts are concentrated in the area of Building 3, and on the west side of Building 1, particularly in the north-west corner of the latter building where a number of coins were found. This may have been a commercial area, just inside the main gate. Other definite female- and child-related artefacts were found in the Building 7, the commander's residence, and between Buildings 12-14, identified respectively as probably taverns and soldiers' barracks (Schönberger 1978, 118, 120). Less certain female- and child-related artefacts were scattered across Barracks 6.

As at Vetera I, there seems to be a relatively close association between definite and less certain female-related artefacts. If Schönberger's identifications of the various buildings and areas are correct, then the specialist craftsmen in Building 3 and the troops, or at least the centurion, in Barracks 6 may have resided with their families within this fort. Either these women, or possibly other women, were involved in commercial and perhaps industrial activities in the areas of Building 1 and Building 12. Given that this fort is identified as a supply station and was unlikely to have housed an active garrison, it is perhaps not surprising to find women integrated into this community as they would have been in a civilian community.

\subsection{Ellingen}

The auxiliary fort at Ellingen covered 0.7 hectares. A wood and earth fort was built here $<\mathrm{em}>\mathrm{c}</ \mathrm{em}>$. AD 120, and a building inscription indicates that this fort was replaced with a stone-built one in AD 182 (Zanier 19951992, 157-62). The fort probably housed a garrison involved in the construction of the frontier fortifications, the <em>Limes </em>

(Zanier 19925, 165-70). The date for the fort's final demise is unknown, but it appears to have been relatively rapid and was probably at the end of the 2nd or beginning of the 3rd century (Allison 2007, 438). This fort was excavated by open plan excavation in the 1980s and published by Werner Zanier in 1992.

The distribution of artefacts associated with gendered activities indicates concentrations of stone and metal-working equipment, with the next most prolific activity being cutting and sharpening (Figure 8 [LINK to PAFigure8.jpg]). There seems to be a notable dearth of combat equipment in this fort, and only one artefact that was positively identifiable as combat dress. However, there is a scattering of artefacts associated with cloth production, notably in the north and south corner towers and around the porticoes of Building B.

Building $\mathrm{C}$ has the greatest concentration of all types of artefacts at this site. Zanier | suggested (19951992, 69-70) that this was rubbish, re-deposited in this building to make a foundation for a new floor, either $\langle$ em $>c</ e m\rangle$. AD 150 or AD 182. He surmised that this material must have been brought in from outside the fort because it contained infant skeletal remains and tubular tiles, of the type used for hypocaust heating and which he | felt were unlikely to have been used in the buildings in this fort (Zanier 19951992, 69, $72,93)$. 
However, infant, or perinatal [LINK to glossary], skeletal remains (Fig. 9 [LINK PAFigure9.jpg]) and tubular tiles (Fig. 10 [LINK to PAFigure10.jpg]) occur elsewhere within the fort. Many of the infant remains were found in pits and as partial skeletons, suggesting that they were $<\mathrm{em}>$ in $s i t u</ \mathrm{em}>$ burials. Such fragile partial skeletal remains are most unlikely to have survived any re-deposition. It is more probable that infant burials were dug into re-deposited material in Building $\mathrm{C}$ and, therefore, that they are associated with the activities of this fort, and possibly with those of this building (for detailed discussion see Allison 2007, 408-412, 429-431).

The distribution plot for other female- and child-related artefacts at Ellingen bears this out, particularly definite female material in Well 4 and in the main street area outside Building C (Fig. 11 [LINK to PAFigure11.jpg]). It is difficult to assess how much of the material within Building $\mathrm{C}$ was re-deposited, but some, at least, of the female- and childrelated artefacts were certainly found in levels above the proposed re-deposited material and so would have belonged to the later occupation of this building (compare Graph 2 [LINK to PAGraph2.jpg] with Graph 3 [LINK to PAGraph3.jpg]).

Other areas which had the main densities of women's and children's artefacts were the streets and gateways (e.g. in Well 1 in the central area which Zanier dated to Period 1 (1995, 97-8), but also Building B. The workshop and administrative areas (e.g. Building D, Area G, and Buildings A and E), had a dearth of female-related material. Two possibly female-related artefacts were found in the upper levels of the latrine associated with this Building F (Shaft 6). Zanier identified this building as the commander's house

during Period $2(19951992,86)$. However, a greater density of female- and child-related material was found in Building B. The prominence of female-related material in Well 4 and the likelihood that infant burials were cut into the re-deposited material under the floor in Building C, suggests that women lived in this building, at least after AD 182.

Thus, the distribution of female- or child-related artefacts at Ellingen indicates that buildings identified as soldiers' barracks, Buildings B and C, had considerable quantities of such material, including most of the infant burials. This implies that women and families were living in this fort, probably with ordinary soldiers, very probably before Septimius Severus' marriage reforms of AD 197, and irrespective of the legitimacy of such families (for more detailed distribution plots for Ellingen, see Allison 2007).

\section{Discussion}

6.1 Presence, habitation and roles of women in these forts

Thus, within these four military bases, artefacts left behind on activity surfaces, in wells and pits, and on rubbish dumps, after a fort has been abandoned, indicate the presence and movements of women and children inside these male domains. Many of the femaleand child-related artefacts - from the gateways, streets and more public areas conceivably belonged to itinerant traders and service people coming into the fort from a settlement outside. While some of the distribution pattern at the legionary fortresses of Vetera I and Rottweil might fit into this category, some of it is conceivably associated 
with officers' households. Such a restricted distribution pattern is less apparent for the other two, later, auxiliary forts, however. At both Oberstimm and Ellingen there seems a prominent pattern for female presences, and very probably residency, within the barracks of ordinary soldiers and craftsmen. Such women were possibly significant players in the activities within these forts, which, at Oberstimm, involved the supply of necessities to other military bases on the frontier. At Ellingen, their movements seem concentrated in the residential areas of ordinary soldiers. Whatever their other activities, these women appear to have been children and so producing soldiers' families, within the fort precinct.

6.2 Implications of the presence of women within these forts Arguments that have frequently been put forward for why women could not have been accommodated within these communities and particularly within soldiers' barracks, include: the supposition that each barrack unit could only accommodate eight soldiers (Petrikovits 1975, 36; Phang 2001, 127); the systematic layout of military forts which does not allow adequate and suitably furbished residences for women and families (see van Driel Murray 1995, 16); and the supposition, by both ancient writers like Herodian and also modern scholars (e.g. Watson 1969, 133); that women were a hindrance to the necessary efficiency of a military unit.

However, calculations of the amount of space required to accommodate a single soldier, or to accommodate a family, are based on very proscriptive approaches to military life, and to human behaviour. Also, in many excavated forts and fortresses the systematic layout of many published fort plans are only hypothetical (e.g. Inchtuthil in Scotland: Webster 1985, fig. 34), as few forts have been comprehensively excavated (see Vetera I, and Chesters near Hadrian's Wall: see de la Bédoyère 2000, fig. 27). And an assumed disruptive, as opposed to a supportive, role for women in military life stems rather from age-old, biased, perspectives on female behaviour (see Van Driel Murray 1995, 19). Roxan has demonstrated that such support could even be financial (Roxan 1991, 465).While Watson argued that soldiers needed to remain celibate, he also acknowledged, contradictorily, the necessity of 'unofficial unions' (Watson 1968, 134-5). In general, our perspectives on the community lives of Roman soldiers in the 1st and 2nd centuries AD need to be rethought. For example, legionary fortresses probably functioned more like towns than as segregated communities.

\section{Concluding Remarks}

Analyses of ancient authors' comments and of structural remains alone, from archaeological excavations, often give proscriptive views of people's lives in the past the views expounded by these authors and those hoped for by the builders of the structures. By incorporating analyses of artefact distribution into our investigations, we can start to question our long-held perceptions on Roman military communities and daily life inside military bases. The importance of a GIS-type environment to this project is that we can rapidly plot and test large amounts of data, and we can change any number of parameters and plots along the way, many times. 
As Gaffney, Stančič and Watson stated 'GIS not an objective observer of pattern implications' (1995, 213). At the Roman Archaeology Conference in Birmingham in 2005, a participant asked me 'when will GIS get beyond being just dots on maps?'. However, it is the visualisation of these artefact distribution patterns, these 'dots on maps', which facilitates their analysis and interpretation. As stated by Stanton Green, 'GIS visual output [is] a substantial methodological aspect' $(1990,7)$. The remains of women's activities that can be identified in the archaeological record are extremely sparse and therefore often considered non-existent or even intrusive. With the type of visualisation, or 'dots on maps' provided by GIS, such faint patterns can be highlighted and the other 'noise' removed, if necessary, to examine both the inter- and intra-site patterning of the less well-understood members of past communities. As stated by Kwan, 'As geographical data .... at fine spatial scales can be assembled and incorporated into a GIS, it is possible to link the trajectories of women's everyday lives ... This would allow a mode of analysis that is more sensitive to scale and context than conventional methods' and 'This mode of analysis ... permits an understanding of women's situations "at a level that does not obfuscate their daily lives through maps and language drawn from instrumental, strategic logic" ([quoted from] Aitken 2002, 364)'.

(Kwan $(2002 b, 651)$

An added factor that obscures the patterns of less prominent evidence is a traditional practice in Roman archaeology whereby a scholar will specialise in one particular artefact type (e.g. fine ceramics) and the results of that scholar's study are not incorporated into the overall artefact analysis or indeed integrated into the overall interpretation of the site (see Allison 1997). This practice has evidently caused a problem in understanding the fort at Ellingen where the conclusions of Peter Schröter, who carried out analyses of the skeletal remains (Zanier 1992, 306), were not included in the initial overall interpretations of the fort.

In a concern about the usefulness of GIS analyses Stanton Green asked 'Can one partition human behaviour into spatial packages?'(1990, 4). Roman forts, with clearly defined structural and spatial limits, would appear to constitute such inbuilt 'spatial packages'. The use of 'legacy data', such as comprehensively published excavation reports from Roman military sites, can show archaeologists, who are still developing their digitised data, the kinds of questions that they will be able to ask these data. For example, if I can find even the smallest traces of women and children in forts with relatively poorly recorded data, then other scholars can use their more carefully recorded sites to deepen our understanding of community life on the Roman frontier in the Early Empire and the roles of women and families in this military domain.

\section{Acknowledgments}

I would like to acknowledge the people who have made this study possible: my technical team who assisted with different aspects and stages of this project - Andrew Fairbairn, Steven Ellis, Pat Faulkner, Paul Newson and Chris Blackall; the excavators and cataloguers of these forts - especially Professor Hans Schönberger, Drs Norbert Hanel and Werner Zanier; and other colleagues who have generously provided advice and 
support, in particular Prof. von Schnurbein, Dr Carol van Driel-Murray, Dr Sebastian Sommers, and Dr Astrid Böhme-Schönberger. I am also grateful to the participants in the session and workshop at the Australian Archeometry conference in Canberra in 2005, and at research seminars at the University of Queensland, the University of Leicester and the University of Wales (Lampeter) for their questions and comments on earlier versions of

this article. Finally I would like to thank the Australian Research Council for funding this research. All plots in this article are currently being produced as on-line ArcIMS plots by the Archaeological Digital-Data Service (University of York).

\section{Bibliography}

Aitken, S., 2002 'Public participation, technological discourses and the scale of GIS', in W.J. Craig, T.M. Harris and D. Weiner (eds) <em>Community Participation And Geographical Information Systems $</ \mathrm{em}>$. London, 357-66.

Allason-Jones, L., 1995 “"Sexing” small finds', in P. Rush (ed.) <em>Theoretical Roman Archaeology: Second conference proceedings $</ \mathrm{em}>$. Avebury, 22-32.

Allison, P.M., 1993 'How do we identify the use of space in Roman housing?', in E. Moormman (ed.) <em>Functional and Spatial Analysis of Wall Painting: Proceedings of the 5th International Congress of Ancient Wall Painting, Amsterdam 1992 Bulletin Antieke Beschaving, Annual Papers in Classical Archaeology<em>, special edition 3. 1-8.

Allison, P.M., 1997 'Why do excavation reports have finds' catalogues?', in C.G. Cumberpatch and P.W. Blinkhorn (eds), <em>Not So Much A Pot, More A Way Of Life <em>. Oxford, 77-84.

Allison, P.M., 1999 'Labels for ladles: interpreting the material culture of Roman households', in P.M. Allison (ed.), <em>The Archaeology of Household Activities $</ \mathrm{em}>$. Routledge, London and New York, 57-77.

Allison, P.M., 2004 <em>Pompeii Households: Analysis of the material culture</em>. Cotsen Institute of Archaeology, UCLA, Monograph 42. Los Angeles (online companion: www.stoa.org/pompeianhouseholds/).

Allison, P.M., 2006a <em>The Insula of the Menander in Pompeii III: The finds, a contextual study</em>. Oxford.

Allison, P.M., 2006b 'Mapping for gender: interpreting artefact distribution in Roman military forts in Germany', <em>Archaeological Dialogues $</ \mathrm{em}>\mathbf{1 3 . 1}, 1-48$ (including discussion). Supplementary colour figures: www.journals.cup.org/abstract_S1380203806211851).

Allison, P.M., 2007 'Artefact distribution within the auxiliary fort at Ellingen: evidence for building use and for the presence of women and children', <em>Bericht der Römisch-Germanishen Kommission</em> 87 (2006), 387-452.

Allison, P.M., forthcoming <em>Mapping Social Behaviour in Early Roman Imperial Nilitary Forts: case studies from the German frontier<em>.

Allison, P.M., Fairbairn, A., Ellis, S. and Blackall, C., 2004 'Extracting the social relevance of artefact distribution within Roman military forts', <em>Internet Archaeology</em> 17. http://intarch.ac.uk/journal/issue17/allison_index.html. 
Baatz, D., $1973<\mathrm{em}>$ Kastell Hesselbach und andere Forschungen am Odenwaldlimes $</$ em>. Römisch-Germanisch Commission. Limesforschungen Band 12. Berlin.

Birley, R., 1977 <em>Vindolanda: a Roman Frontier Post on Hadrian's Wall</em>. London.

Bishop, M.C., 1987 'The evolution of certain features', in M. Dawson (ed.), <em>Roman military equipment: The Accoutrements of War, Proceedings of the third Roman military equipment seminar</em>. Oxford. 109-39.

Bishop, M.C., 1988 'Cavalry equipment of the Roman army in the first century A.D.', in J.C. Coulston (ed.), <em>Military Equipment and the Identity of Roman Soldiers: Proceedings of the fourth Roman military equipment conference $</ \mathrm{em}>$, Brit. Archaeol. Rep. International Series 394, Oxford, 67-196.

Böhme-Schönberger, A., 2002 'Die Distelfibel und die Germanen', in K. Kuzmová, K. Pieta and J. Rajtár (eds), <em>Zwischen Rom und der Barbaricum, Festschrift für Titus Kolnik zum 70. Geburtstag</em>. Nitra, 111-16.

Bowman, A.K. and Thomas, J.D., $1994<\mathrm{em}>$ The Vindolanda Writing-tablets (Tabulae Vindolandenses $I I)</ \mathrm{em}>$. London.

Caesar <em>Bellum Africanum</em> (transl. A.G. Way 1955). Loeb Classical Library. London and Cambridge, Mass.

Casella, E., 2006 “"Safe” genders', <em>Archaeological Dialogues $</$ em> 13.1, 25-27.

Cassius Dio, <em>Roman History<em> (transl. E. Cary 1968). Loeb Classical Library. Cambridge, Mass. and London.

De la Bédoyère, G., 2000 <em>Hadrian's Wall: history and guide</em>. Stroud.

Deschler-Erb, S., 1998 <em>Römische Beinartefakte aus Augusta Raurica: Rohmaterial, Technologie, Typologie und Chronologie</em>. Augst.

$<\mathrm{em}>$ Digesta $</ \mathrm{em}>$. 'The Digests of Justinian'. T. Mommsen, and P. Krueger (eds) (English translation A. Watson (ed.) Philadelphia, $\langle\mathrm{em}>\mathrm{c}</ \mathrm{em}>$. 1985).

Dixon, S., 2001 <em>Reading Roman Women: Sources, Genres and Real Life</em>. London.

Driel-Murray, C. van, 1994 'A question of gender in a military context', $<\mathrm{em}>$ Helinium</em> 34.2, 342-62.

Driel-Murray, C. van, 1995 'Gender in question', in P. Rush (ed.), <em>Theoretical Roman Archaeology: Second Conference Proceedings</em>. Avebury, 3-21.

Driel-Murray, C. van, 1997 'Women in forts?', <em>Jahresbericht der Gesellschaft Pro Vindonissa</em>, 55-61.

Franke, R., 2003 <em>Arae Flaviae V: Die Kastell I und II von Arae Flaviae/Rottweil und die römische Okkupation des oberen Neckargebietes $</ \mathrm{em}>$. Stuttgart.

Gaffney, V., Stančič, Z. and Watson, H., 1995 'The impact of GIS on archaeology: a personal perspective', in G. Lock and Z. Stančič (eds), <em>Archaeology and Geographical Information Systems: A European Perspective</em>. London, 211-29.

Garnsey, P., 1970 'Septimius Severus and the marriage of soldiers', <em>Californian Studies of Classical Antiquity</em> 3, 45-53.

Goldworthy, A. and Haynes, I. (eds), $1999<\mathrm{em}>$ The Roman Army as a community</em>, Journal of Roman Archaeology Supplement Series 34. Portsmouth. 
Green, S., 1990 'Approaching archaeological space: an introduction to the volume', in K.M.S. Allen, S.W. Green and E.B.W. Zubrow (eds), <em>Interpreting Space: GIS and archaeology</em>. London, New York and Philadelphia, 3-8.

Hanel, N., 1995 <em>Vetera I: Die Funde aus den römischen Lagern auf dem Fürstenberg bei Xanten</em>. Cologne and Bonn.

Hassall, M., 1999 'Homes for heroes: married quarters for soldiers and veterans', in A. Goldsworthy and I. Haynes (eds), <em>The Roman Army as a Community</em>. Portsmouth: Rhode Island: Journal of Roman Archaeology Supplementary Series 34, $35-40$.

Hermon, S., Niccolucci, F., Alhaique, F, Iovino, M-R. and Leonini, V., 2004 'Archaeological typologies - an archaeological fuzzy reality', in K. Fischer Ausserer, W. Börner, M. Goriany and L. Karlhuber-Vöckl (eds). <em>Enter the Past: The Eway into the Four Dimensions of Cultural Heritage, CAA2003, Computer Applications and Quantitative Methods in Archaeology, Proceedings of the 31st Conference, Vienna, Austria, April 2003</em>. Oxford, 30-33.

Herodian, <em>Histories </em> (transl. C.R. Whittaker, 1969). Loeb Classical Library. London and Cambridge, Mass.

Hoffmann, B., 1995 'The quarters of legionary centurions of the Principate', $<\mathrm{em}>$ Britannia $</ \mathrm{em}>\mathbf{2 6}, 107-51$.

Juvenal, <em>Satires </em> (transl. G.G. Ramsay, 1918). Loeb Classical Library. London and Cambridge, Mass.

Kampen, N. (ed.), 1996 <em>Sexuality in Ancient Art: Near East, Egypt, Greece, and Italy</em>. Cambridge.

Kwan, M., 2002a 'Is GIS for women? Reflections on the critical discourse in the 1990s', $<\mathrm{em}>$ Gender, Place and Culture</em> 9, 271-9.

Kwan, M., 2002b 'Feminist visualization: re-envisioning GIS as a method in feminist geographic research', <em>Annals of the association of American geographers $</ \mathrm{em}>$ 92, 645-61.

Lehner, H., 1907 'Vetera. Ausgrabungen in den Jahren 1906-1907', <em>Bonner Jahrbücher </em> 116. 302-43.

Lehner, H., 1912 'Vetera. Ausgrabungen in den Jahren 1910-1912', <em>Bonner Jahrbücher $</ \mathrm{em}>$ 122, 311-42.

Lehner, H., $1930<\mathrm{em}>$ Vetera: Die Ergebnisse der Ausgrabungen des Bonner Provinzialmuseums bis 1929</em>. Frankfurt.

Nandris, J.G., 1981 'Aspects of Dacian economy and highland zone exploitation', $<$ em>Dacia</em> N.S. 25, 231-54.

Petrikovits, H. von, $1975<\mathrm{em}>$ Die Innenbauten römischer Legionslager während der Prinzipatszeit $</ \mathrm{em}>$. Westdeutscher.

Phang, S., $2001<\mathrm{em}>$ The Marriage of Roman Soldiers (13 BC-AD 235): Law and Family in the Imperial Army</em>. Leiden.

Quilici, L., 1974 'Artena (Roma) - Saggi di scavo all Cività', <em>Notizie degli Scavi $</$ em> 28, 56-88.

Robinson, H.R., 1975 <em>The Armour of Imperial Rome<em>. London.

Roxan M., 1991 'Women on the frontiers', in V.A. Maxfield and M.J. Dobson (eds), <em>Roman Frontier Studies 1989: proceedings of the XVth International Congress of Roman Frontier Studies<em>. Exeter, 462-7. 
Schönberger, H., 1978 <em>Kastell Oberstimm, die Grabungen von 1968 bis $1971</$ em>. Berlin.

Smith, R., 1972 'The army reforms of Septimius Severus', <em>Historia</em> 23, 481500.

Southern, P. and Dixon, K.R., $1996<\mathrm{em}>$ The Late Roman Army</em>. New Haven.

Spiedel, M.A., $1996<\mathrm{em}>$ Die römischen Schreibtafel von Vindonissa</em>. BadenDättwil.

Tomášková, S., 2006 'Next stop: gender. Women at Roman military forts in Germany', $<\mathrm{em}>$ Archaeological Dialogues $</ \mathrm{em}>13.1,20-25$.

Treggiari, S., 1976 'Jobs for women', <em>American Journal of Ancient History</em> 1, 76-104.

Watson, G.R., $1969<\mathrm{em}>$ The Roman Soldier</em>. London.

Webster, G., $1985<\mathrm{em}>$ The Roman Imperial Army of the First and Second Centuries A.D. $<\mathrm{em}>$. London.

Zanier, W., $1992<\mathrm{em}>$ Das Römische Kastell Ellingen </em>. Mainz am Rhein.

Zimmermann, H.-J., $2001<\mathrm{em}>$ Fuzzy Set Theory and its Applications $</ \mathrm{em}>$ (4th edition). Boston, Dordrecht and London. 


\section{List of figures}

Graph 1: Vetera I,- correspondence analysis between groups of functionally related buildings and areas, and gender categories at (compiled by A. S. Fairbairn). [LINK to PAGraph1.jpg]

Graph 2: Ellingen, density of female- and child-related items per building area (minus wells, stray finds). [LINK to PAGraph2.jpg]

Graph 3: Ellingen, density of female- and child-related items per building area (minus wells, stray finds, and material from redeposited levels in Building C). [LINK to PAGraph3.jpg].

Figure 1: Map of Germany showing sites analysed in the 'Engendering Roman Spaces' project. [LINK to PAFigure1.jpg]

Figure 2: Vetera I, distribution of gendered activities, plotted according to gender. Stray finds are plotted in the large pie chart to the bottom right of site plan. Key: ZFE = possibly female-related; ZFE_CH = possibly female- or child-related; $\mathrm{ZCH}=$ possibly child-related; MA = male-related; ZMA = possibly male-related;

ZMA_FE = possibly male- or female-related. [LINK to PAFigure2.jpg]

Figure 3: Vetera I, distribution of artefacts associated with women and children, plotted according to gender. Key: $\mathrm{FE}=$ female-related; $\mathrm{ZFE}=$ possibly female-related; $\mathrm{ZFE} \_\mathrm{CH}=$ possibly female- or child-related; $\mathrm{ZCH}=$ possibly child-related. Large red dot in Building a represents a necklace of 21 glass beads. [LINK toPAFigure3.jpg]

Figure 4: Rottweil Forts I and II, distribution of gendered activities, according to activity. Key: $\mathrm{CS}=$ cutting and sharpening equipment; $\mathrm{E}=$ combat equipment; $\mathrm{G}=$ gaming items; $\mathrm{SM}=$ stone- and metal-working equipment; $\mathrm{T}=$ toilet items; $\mathrm{W}=$ writing equipment; WL = wood- and leather-working equipment. [LINK to PAFigure4.jpg]

Figure 5: Rottweil Forts I and II, distribution of artefacts associated with women and children, according to gender. Key: FE = female-related; ZFE = possibly femalerelated; ZFE_CH = possibly female- or child-related. [LINK to PAFigure5.jpg]

Figure 6: Oberstimm, distribution of gendered activities, according to activity. Key: $A=$ Agriculture; $\mathrm{CS}=$ cutting and sharpening equipment; $\mathrm{E}=$ combat equipment; $\mathrm{G}=$ gaming items; $\mathrm{SM}=$ stone- and metal-working equipment; $\mathrm{T}=$ toilet items; $\mathrm{W}=$ writing equipment; $\mathrm{WL}=$ wood- and leather-working equipment; $\mathrm{WM}=$ weighing and measuring equipment. [LINK to PAFigure6.jpg]

Figure 7: Oberstimm, distribution of artefacts associated with women and children, according to gender. Key: $\mathrm{FE}$ = female-related; $\mathrm{ZFE}=$ possibly female-related; ZFE_CH = possibly female- or child-related; $\mathrm{ZCH}=$ possibly child-related. [LINK to PAFigure7.jpg]

Figure 8: Ellingen, distribution of gendered activities, according to activity. Key: $A=$ Agriculture; $\mathrm{CS}=$ cutting and sharpening equipment; $\mathrm{E}=$ combat equipment; $\mathrm{G}=$ gaming items; $\mathrm{SM}=$ stone- and metal-working equipment; $\mathrm{T}=$ toilet items; $\mathrm{W}=$ writing equipment; WL $=$ wood- and leather-working equipment. [LINK to PAFigure8.jpg]

Figure 9: Ellingen, distribution of infant and adult skeletal remains. [LINK to PAFigure9.jpg]

Figure 10: Ellingen, distribution of tubular tiles. [LINK to PAFigure10.jpg] 
Figure 11: Ellingen, distribution of artefacts associated with women and children, according to gender. Key: $\mathrm{FE}=$ female-related; $\mathrm{ZFE}=$ possibly female-related; ZFE_CH = possibly female- or child-related; $\mathrm{CH}=$ child-related. [LINK to PAFigure11.jpg] 